\title{
SOCIAL EXCLUSION THROUGH MASS TRANSIT SYSTEMS: A comprehensive assessment of São Luís' buses-network
}

\author{
Diogo Pereira Pires Ferreira ${ }^{12}$, \\ Rômulo Orrico Dante Filho ${ }^{3}$ \\ Valentina Tridello ${ }^{14}$ \\ 1 IUAV University of Venice, Venice, Italy \\ 2 Fundação de Amparo a Pesquisa e Desenvolvimento do Estado do Maranhão - FAPEMA, São Luís, \\ Maranhão \\ 3 Federal University of Rio de Janeiro UFRJ COPPE, Rio de Janeiro, Brazil, \\ romulo@pet.coppe.ufrj.br \\ 4 Tecnische Universiteit Delft, TUDelft \\ Thesis diretor: Paola Viganó \\ Thesis co-director: Rômulo Orrico Dante Filho \\ diogopiresferreira@gmail.com
}

\begin{abstract}
This paper summarizes Mass Transit Systems (MTS) networks datasets, highlighting the lack of contribution on promoting access to opportunities and city-assets for the most vulnerable segments of the population. As case study São Luís, the city-capital of Maranhão holding the lowest average income in Brazil. Although social inequity issues seem ubiquitous in numerous Brazilian cities, this study reveals evidence of complications on social and spatial segregation being supported by a not reliable MTS service. It also produces an expensive and inefficient system, opening room for informal transports. Lack of subsidies constrains the system to provide a limited service to 'On-Peak' hours destinations, rising time-dependent users, and inhibiting the right to the city. A framework developed on system's behavior analyze both 'On-Peak'/'Off-Peak' periods identified deficiencies hidden behind MTS network's capillarity, resulting in evidence of social exclusion and spatial injustice promoted by long headways, which does not ease access equally the city.
\end{abstract}

Key words: Public transportation, social exclusion, network, peak hours 


\section{Introduction}

Accessibility to Mass Transit System (MTS) when estimated by a short walking distance from its stations to the population to be served (Marks et al., 2016) fails to ignore spatial-temporal timetables variations of MTS network, routes available and the walking distance necessary to access city assets. There is an emerging literature with evidence of MTS' inability or difficult to provide wide access to city assets for the users. Hence, healthcare, services, sustenance, education, employment, leisure, culture, social and other facilities or even job and educational opportunities roughly supplied for time-dependent users, limited to the MTS' service timetable (Fransen et al. 2015; Tenkanen et al. 2016).

Fostering public and non-motorized transport has been considered a way to address social exclusion issues since MTS is intended to be the first affordable option to commute in cities (Fransen et al. 2015; Ferreira and Lagemann, 2016; Woldeamanuel and Kent; 2016). It is clear the evidence in places like the case study of this paper, São Luís the capital city of Maranhão, a state holding the lower average income index in Brazil (IBGE, 2015, p.89). It highlights the importance of its MTS, also when non-motorized transportation is unfeasible due to the notable urban sprawl, and the lack of basic infrastructure such as sidewalks, already mentioned in previous investigations (Ferreira, 2011a, 2011b, 2012; IBGE, 2016d). From one side, the expenses with urban transportation in low-income segments represent an average of $22 \%$ of family earnings (IBGE, 2015b:292$315)$. On the other side, the intense urban sprawl brings the challenge to maintain the capillarity of the MTS economically, resulting in a small capacity and less efficient network (Orrico et al., 2012) since its financial resources based only on the current demand. Nevertheless, although São Luís' public transport does not have any particular priority advantage to improve time-travel, it holds outstanding numbers. The city, which has 1.082.935 inhabitants' (IBGE, 2016) counts on an average of 600.000 daily passengers (SMTT. 2017), together with a low motorization index of 208 vehicles per every 1000 inhabitants, whereas the number climbs to 306 if included motorcycles (Denatran, 2017).

In recent years, Brazilian cities have witnessed a significant growth on policies for mass transport, such as the enacted Urban Mobility Law 12.587/2012, a Constitution Amendment PEC-90/2015 introducing in the Federal Constitution the transport as a social right (Brasil, 2015; Brasil 2016) among many others. Those new policies are intended to adjust the priorities given in the last three decades since most of the transport investments in the country were focused on responding to the private motorization index growth (Daros, 1995; Lindau et al. 2015). Although many on-going resources have been committed to building an infrastructure that aims at the improvement of public transport systems, there are still several unassisted gaps on modeling MST networks and its timetables enhancing social exclusion in which are often hidden behind system's capillarity. Hence, this paper has the city of São Luís as a case study focusing on its MTS network. This study assesses how the MTS network narrows, constraints or limit the access to city features, due to inefficient headway. This study also considers the hypothesis that an optimum MTS aiming at democratic and equitable access to contemporary city's dynamics requires a capillarity and isotropic network service to promote general accessibility and increase urbanity. This hypothesis also inquires on its opposite, which is suggested by the vast and popular literature, restricting networks to a hierarchical feeder-trunk system, often arranged in a Hub \& Spoke model. The findings of this investigation reveal the effects of network and services arrangements as lack of contribution to provide equal access to opportunities in the city, particularly for the most vulnerable segments of the population. Finally, this study contributes to the strand of literature on strengthening the right to mobility, social justice and the city, the idea of spatial democracy, the new urban question, spatial justice and the fair city (Harvey, 1988; Sen, 2009; Soja, 2010; Secchi, 2013; Ischia, 2016).

\section{Literature review}

As highlighted by Orrico (2013:6), the existing methods to conceive MTS networks often aims at the purpose of tackling the most significant volumes of commuting, instead of consolidating emerging, projected or planned cores in which the city wish and should foster. It happens since major MTSs in Brazil doesn't have subsidies and so private operators that run public transport are economically constrained to resources coming from the ticket-fare. That is, the amount raised by each ticket paid should be enough to cover the 
existing service and achieve profits. This aspect also underlines the high number of passengers using MTS in Brazil, despite the deficient quality in most of the cases (Wright and Hook, 2008, p.164; Gutiérrez, 2013; CAF., 2011).

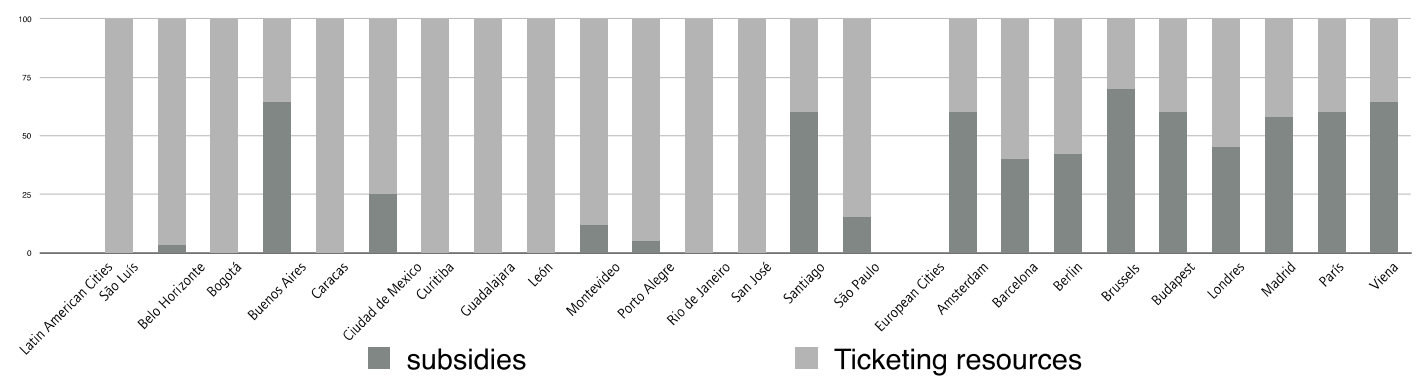

Fig. 1: Graphic shows the percentage of subsidies provided for MTS service in different cities: on the left, Latin American cities, on the right, European Cities (CAF. 2011)

As a consequence, to maintain the system working, the MTS operators hunt for passengers and constrains the system service travels based 'On-Peak' times. On the one hand, it struggles to keep a good passenger per $\mathrm{km}$ index $(\mathrm{PKI})$. On the other side, the search for increasing this index results in overcrowded buses. These challenges were enhanced by previous studies in São Luís, Anápolis, Porto Alegre and other cities in Brazil (Ferreira, 2011; Metroplan, 2013; Ferreira and Araujo, 2013; Mendonça, 2016).

Authors have recently highlighted lack or ineffective mobility as evidence that contributes to social exclusion and time-dependent users (Fransen et al 2015; Grengs, 2015; Tenkanen, et al., 2016). Moreover, investigations on this issue are not constrained to developing economies. As an example, the temporal variation of how fast the population can reach the closest grocery store in a case study of Helsinki (Figure 2), highlights travel time by private car are significantly lower when compared to public transport. It also notices the proportion of the population on reach area changing along different periods of the day (Tenkanen, et al., 2016), whereas similar situations in São Luís were found some areas that are just reachable by car (Ferreira, 2011a). The mentioned situation happens since there is a lack of sidewalks and working MTS' routes to certain areas (Ferreira, 2011a).
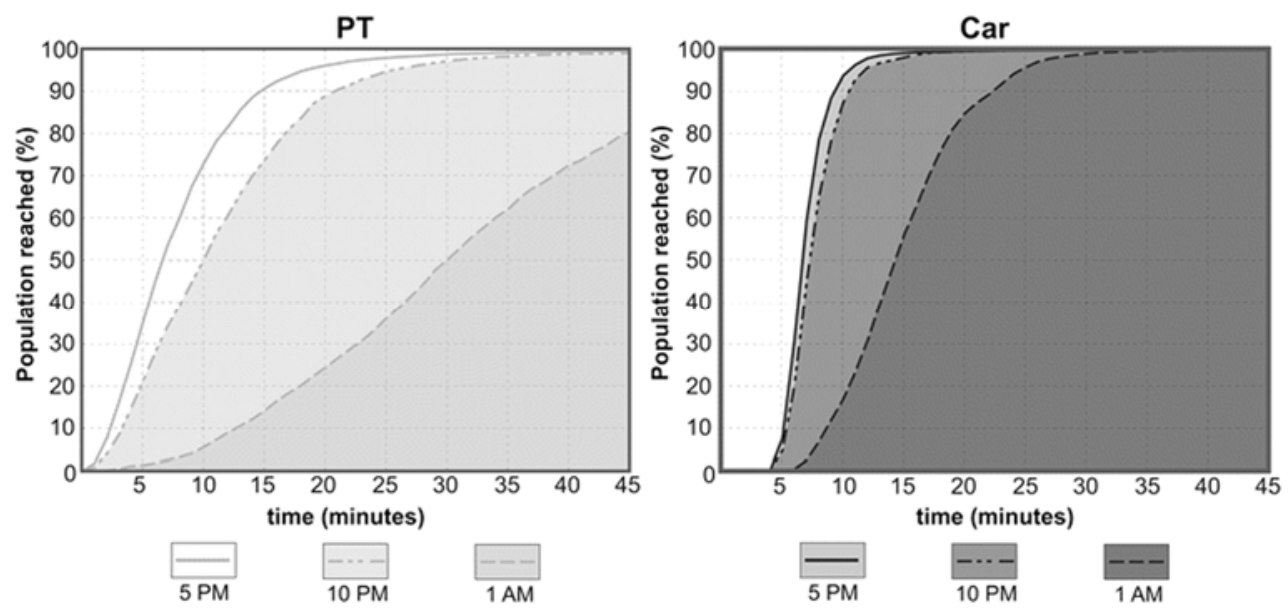

Fig. 2: Research on accessibility to healthy food groceries stores in Helsinki. The graphic above spreads the time to commute (Axis $\mathrm{X}$ ) according to the population reached (Axis Y). On the left, Public Transport (PT), on right private transport (Car) (Tenkanen, et al., 2016)

Evidently, the necessity to reach specific destinations differs for each of our societies. The literature on topological methods and strategies to develop mass transit networks is well served since years ago by different 
investigations. Such as Losch (1954) on 'Economics of Location', Haggett (1965) on optimization of routes. As well exploring both hierarchical and isotropic approaches. Followed by Byrne \& Vuchic (1972) and later Newell (1979) defending hierarchical systems such as hub and spoke. And finally, Thompson's (1977) testing a grid system. However, to unveil a network design, it is known that most of the MTS routes are formulated as a mathematical programming problem, working together with a set of variables (Friesz and Shah, 2001). Equations and algorithms are used to form several possible applications dealing with Origin and Destination (OD) pairs (Fernández et al., 2008). Trending methods such as Mix Logit and Probit have even the capacity to extract a calibration to give priority to vulnerable social groups in the analysed area (Train, 2003; Ortúzar \& Willumesen, 2011). However, Herce (2009) highlights that as more variables added, more difficult is to adjust, hence more errors to incorporate. Nevertheless, is acknowledged to obtain or update an OD matrix which supports a network design depends on a complex and costly process (Ortúzar \& Willumesen, 2011), also identified recently considering existing technology (Bertoncini, 2010). Despite the resources to create an OD matrix, today's cities are even more dynamics, which results in new ways to design MTS network based urban strategies are taking places, such as the Orthogonal System of Barcelona (TMB, 2017) or the Network Redesign of Baltimore (MTA, 2015). It must be taken into account that cities offer a comprehensive range of assets, opportunities inside each urban context the question of mobility - particularly the idea of general accessibility, of each place accessible at any time, as a right of its citizens (Secchi, 2014). Therefore, if considered the right to the city or the right to (mobility in) the city, it becomes difficult put the rights inside the formula as a metric.

\section{Study Area}

The city of São Luís, the capital of Maranhão, is located on an island namely as 'Upaon-Açu' ('Big Island' in native language), near to the Brazilian northeast coastline. This island is shared with other three smaller cities, in which are part of the "Grande São Luís Metropolitan Region," adding up to 1.4 million inhabitants in total (IBGE, 2016). The population growth and the urbanized areas evidence the conurbation among those cities, although the MTS system is not integrated (Figure 3), a drawback for public transit users.
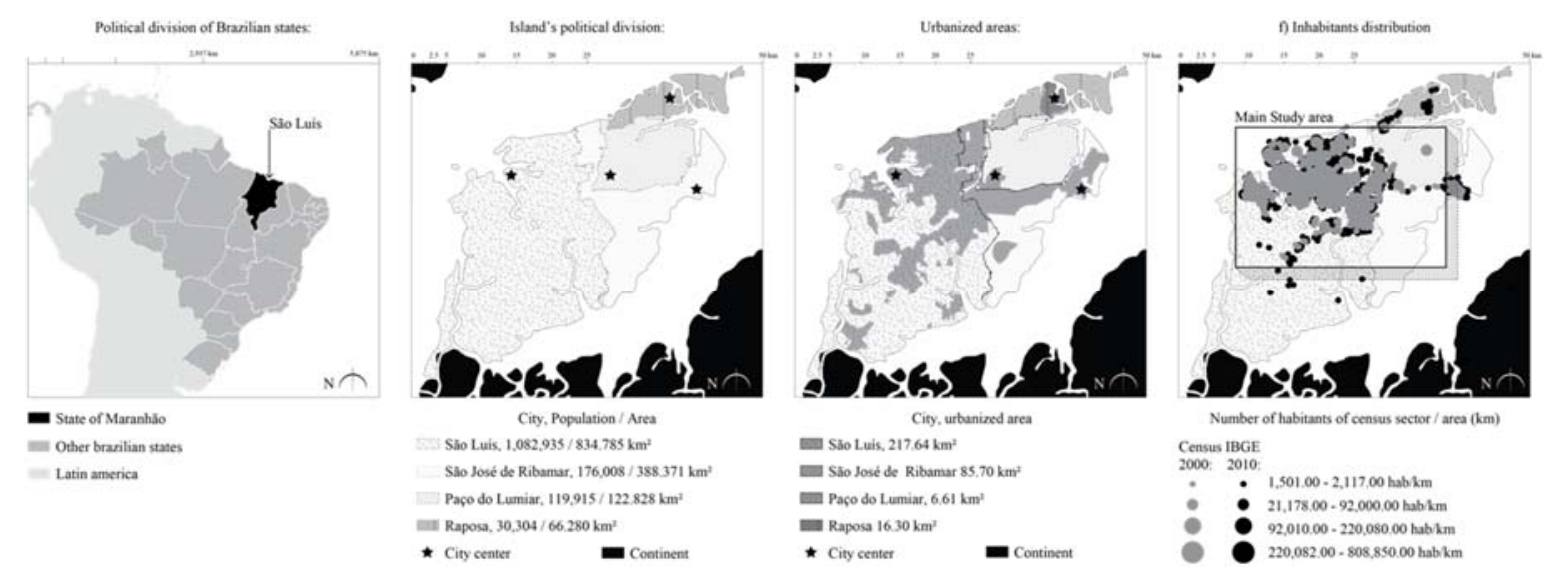

Fig. 3: Maps of political divisions, urbanized areas, inhabitants' distribution. (Self-elaboration based on IBGE 2010 datasets)

There are two primary entities responsible for the urban mobility in the island. The Municipal Secretary of Transit and Transport of São Luís (SMTT), which is driven by the public power of the city of São Luís, and the State Agency of Urban Mobility and Public Services (MOB), driven by the Maranhão State Government. The lack of integration of MTS makes harder as for the passenger to understand stops, access information on routes, as also to thrive studies like the investigation for this paper. The SMTT has authority on urban lines, which counts up to 174 routes with a fleet of 855 buses, which runs monthly a total amount of 5.035,6 km carrying 12,243,695 passengers according to data given by the entity taking the December 2016 as a basis. MOB has authority on 69 routes of semi-urban and inter-urban lines, plus water boats and ferries, according to provided data from each source. According to the last census, people commuting to work or study in adjacent city counts 27,414 from Paço do Lumiar (38\%), 3,085 from Raposa (17\%), 39,227 São José de Ribamar (35\%) 
and finally, 59,394 from São Luís (8\%). This data regardless the mode of transport (IBGE, 2010b). Recently, both agencies started to stress and tackle some fundamental challenges, such as making regular audits and supervision. It was officially reported many issues, such as cases of operators holding their buses or boats at first stop, advising passengers to wait until the vehicle gets full, ignoring the timetable (Azevedo, 2016). From the total number of 243 lines, 140 are integrated by its electronic ticketing as through four terminals existing in the city, plus one in the industrial area. Although capillary, most of the lines function among trunks or feeders to terminals based on a spoke-hub method (Figure 4). Often, to go across the whole city by MTS, for instance, possibly shall be needed two transfers.

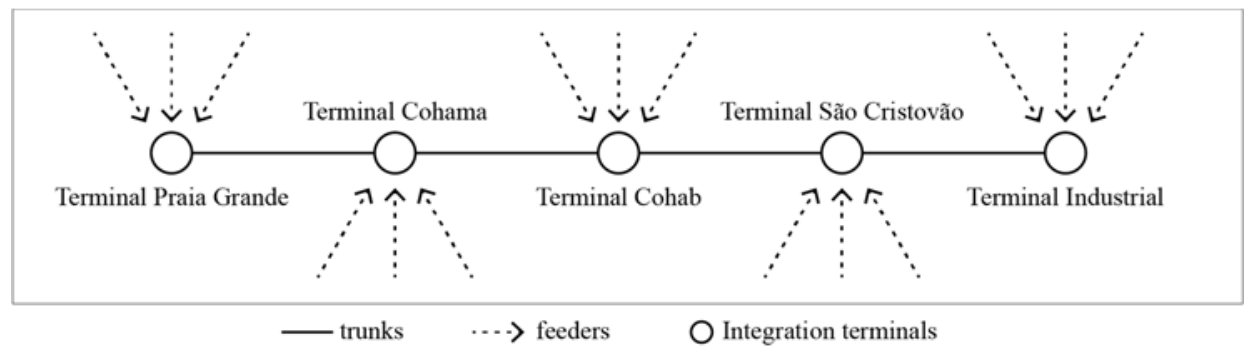

Fig. 4: Scheme of feeders and trunks of existing São Luís' MTS (Self-elaboration based on SMTT 2017 dataset)

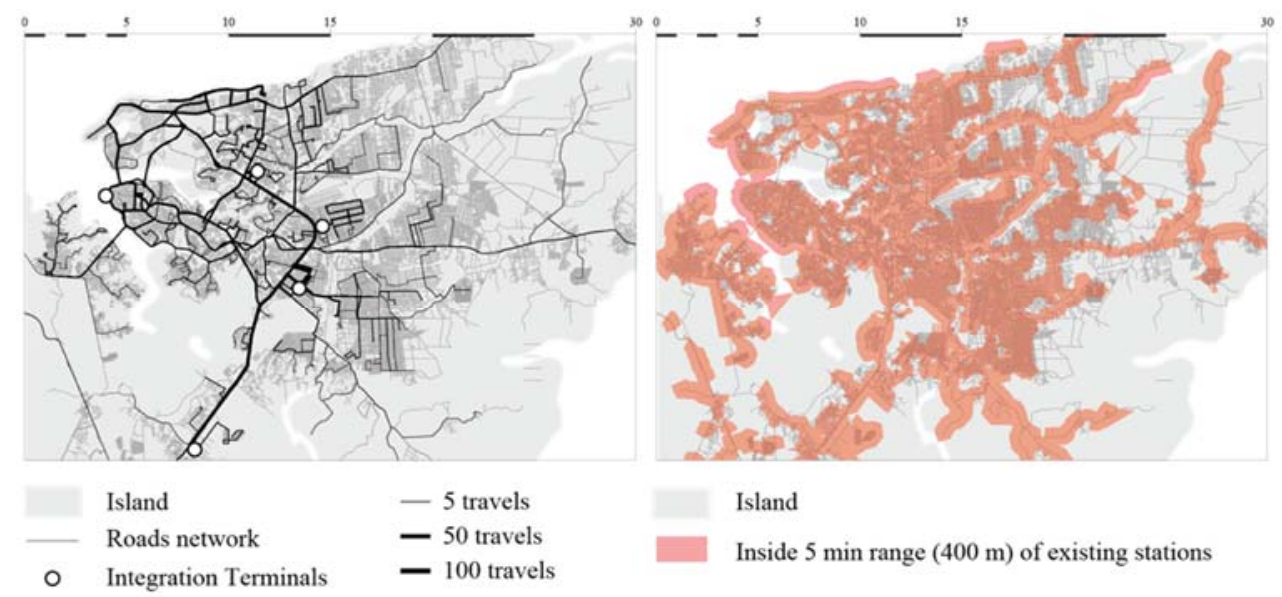

Fig. 5: the MTS network with its travels density (left) station's $400 \mathrm{~m}$ range (right) (Self-elaboration based on SMTT and State agency МOB 2017 datasets)

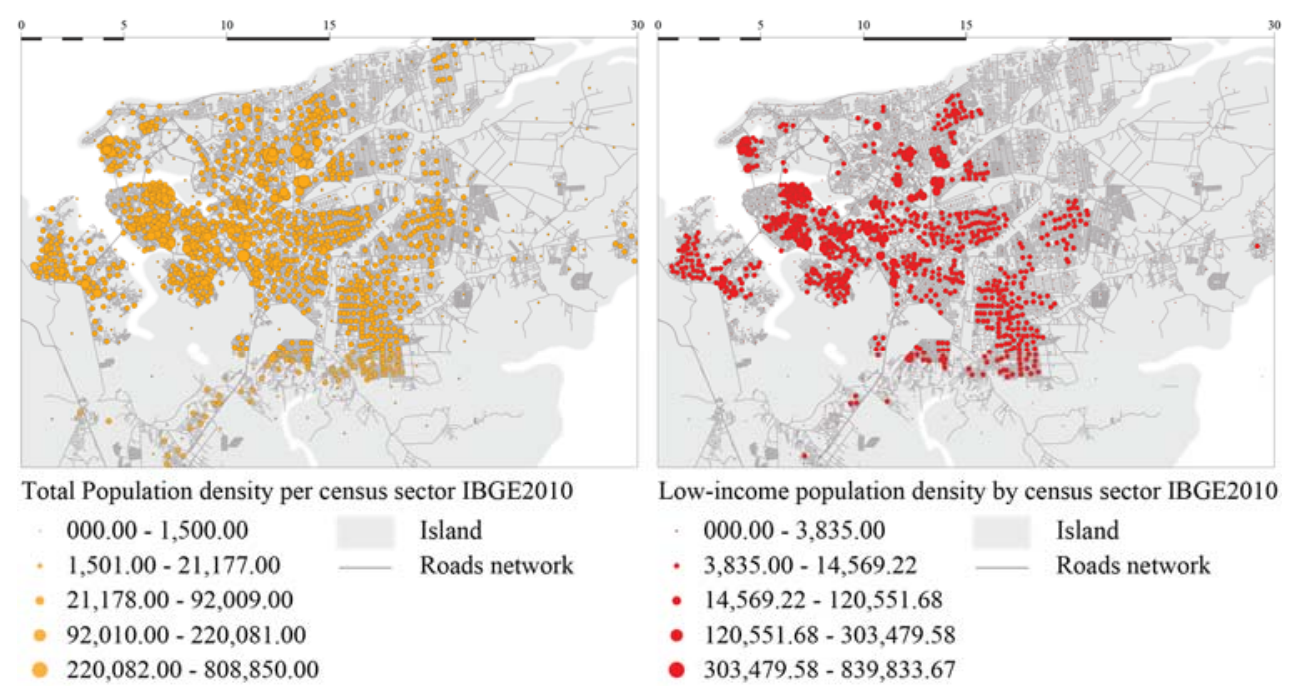

Fig. 6: full population density (left), low-income population density (right) (Self-elaboration based on IBGE census sectors, 2010) 
Unquestionably, the extensive MTS routes network covers almost entirely the whole urban area, as considering 5 minutes (400 meters) walking distance from the working stations. However, it does not consider limitations on existing timetable or number of performed travels, which are assessed further more in this paper (Figure 5). Yet, São Luís records concerning income conditions, having the number of households with monthly income less than half minimum wage per person within the city of São Luís on $40 \%$ (Figure 6), almost half of population with an extremely low-income condition. It is the second worst in its state, placed on 216 of 217 municipalities (IBGE, 2016c). This low-income predominant situation aggregated to urban sprawl ends up increasing the dependency of most of the inhabitants of this region relying on MTS to commute. Affordable options as non-motorized transport is not encouraged since the urban sprawl increases the distance and creates a scattered pattern without mix-use, not attractive for pedestrians or cyclists. To sum up, this car-scale city records very low standards on quality of public space, only $11 \%$ of the existing urban residences have adequate urban infrastructure with presence of sidewalk and pavement, and $32 \%$ of existing urban residences are followed by tree-lined street (IBGE, 2016d). Low-income population is located on non-privileged inner areas of the territory, whereas parks and beaches line up $30 \mathrm{~km}$ on the north coast of the island (Figure 6). Although real estate, land costs, and other aspects drove the city to this spatial segregation, this investigation assesses how its MTS accentuates this segregation and social exclusion.

\section{Methodology}

\subsection{Data collection}

A qualitative analytic method based on in situ empirical observations highlighted a frequent accumulation of MTS' users in certain bus stops along the day, and so assess the São Luís' MTS anomaly on social exclusion and time-dependent users. A proper data collection at official entities was needed to obtain more precise conclusions.

Data collection are here based on crossing spatial data using geographical information systems (GIS) to visualize, unveil and point out the (lack of) range and accessibility of the existing MTS of the case study. Primary data sources are based on available data of Census 2000 and 2010 conceived by the Brazilian Institute of Geography and Statistics (IBGE), together with the National Infrastructure Spatial Data (INDE), a Federal Government entity on geospatial data. These two data sources are internationally known since they have comprehensive coverage on scales, having detailed information divided by census sectors. The base map of general streets networks used to develop analysis was obtained from the Open Street Map platform (OMS). The authors updated the OMS street network under verifications of Google Maps imagery service from 2017, without suitable modifications affecting MTS network. The MTS network data source was obtained in each responsible entity. The State Agency - MOB has information of the existing routes available online on the official entity website. The municipal body of transit - SMTT gave detailed monthly operation data and reports to develop the analysis.

Empirical qualitative observations are so here combined with quantitative data collected from sources previously mentioned overlapping with data of existing MTS of São Luís to assess social exclusion along daytime, allowing to highlight time-dependent users. The major datasets needed to develop this assessment on social exclusion are the following:

a) Existing bus network: all routes of existing lines of the MTS

b) Existing bus stops: all bus stops of the existing MTS

c) Quantity of travels scheduled for each line

d) Quantity of travels effectively performed during the operation

e) Distribution of general population and low-income population of the city

Although datasets a), b) and c) are basic and public information in which any MTS needs to realize to inform its users on how to commute using its routes, it was not easy to access. It wasn't available online on their 
official website, neither on bus stops or terminals. To access this information protocols and documents were requested by the entity, what also shows that the MTS works for captive users. Was also assessed to reach the information throughout the cooperative online public platform, such as Moovit, but SMTT warned on outdated or not accurate on such platforms. Data given by the SMTT are based on the operation performed from December 2016 until February 2017.

\subsection{Formulation of analysis framework and data compilation}

Although peak times may vary according to the distance between cities of some metropolitan regions (METROPLAN. 2013), it was verified that this behavior does not apply in this case. Hence, the timetable given of dataset c) allows visualizing the accumulated amount of travels of all lines programmed by both systems, urban and semi-urban respectively (Figure 7). The next graphics disclose the number of journeys performed by the MTS divided by hour along week working days, Saturdays, and Sundays. Hence, Figure 7 displays the total scheduled service of each hour, i.e. 5 am represents total the sum of all travels of every operating route working from 05:00 am until 05:59 am. Therefore, by having the assistance of this Figure, is underlined here the peak time patterns from 6 am until 9 am, and later from $5 \mathrm{pm}$ until $8 \mathrm{pm}$, with a total amount of 6 hours, which here are considered as 'On-Peak'. Since the operational time from 12 am until 04 am is extremely low or inexistent, they are not considered in the calculations. Besides, the so remaining 14 hours are here considered as 'Off-Peak'. As Saturdays and Sundays do not display a clear peak time, both days are here considered as following same definitions of working days 'On-Peak' and 'Off-Peak'. After spreading on 24h the dataset c) and applying dataset d), a percentage index is here used to serve as a metric for measuring the real availability of a route along its timetable, spreading on $24 \mathrm{~h}$ on working days or weekends (Figure 8). As dataset d) is given per line, it is possible to quantify the effective amount of travels performed by each route along the month. Among the datasets obtained to develop this research, the passengers' data was given in a monthly total, hence would be unprecise if used to correlate the demand to headways.
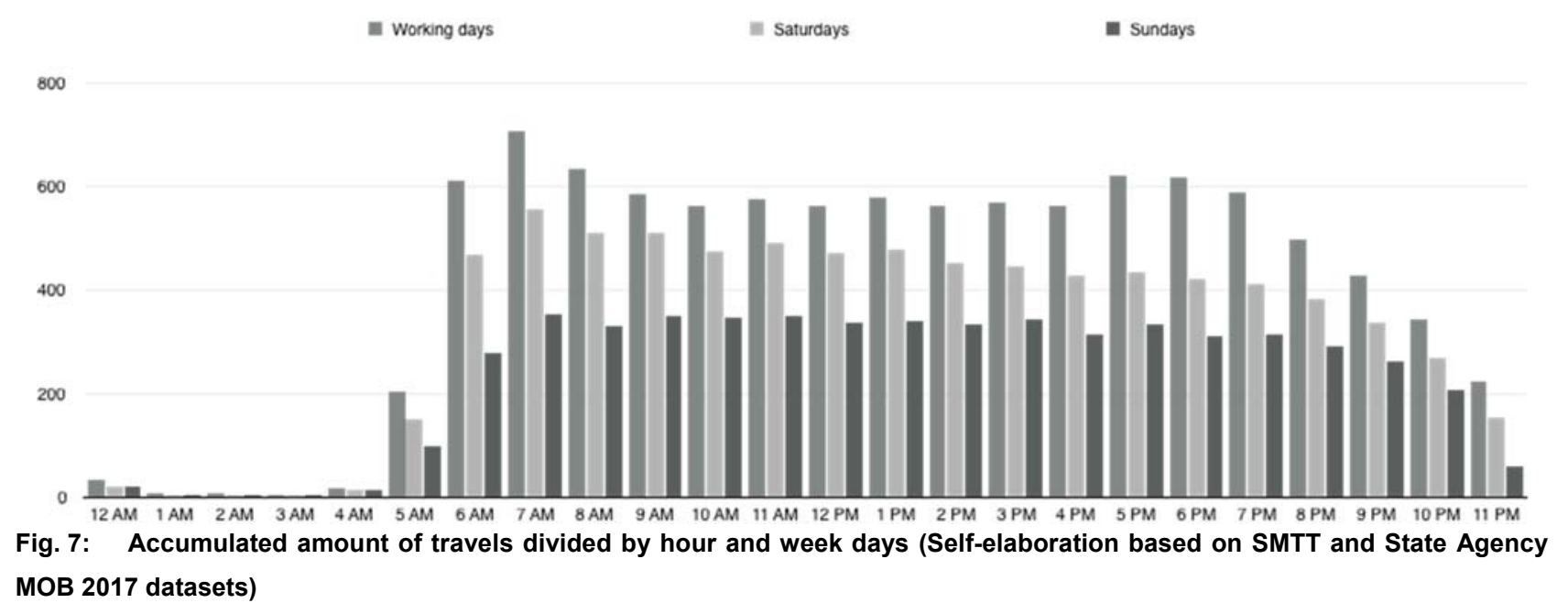

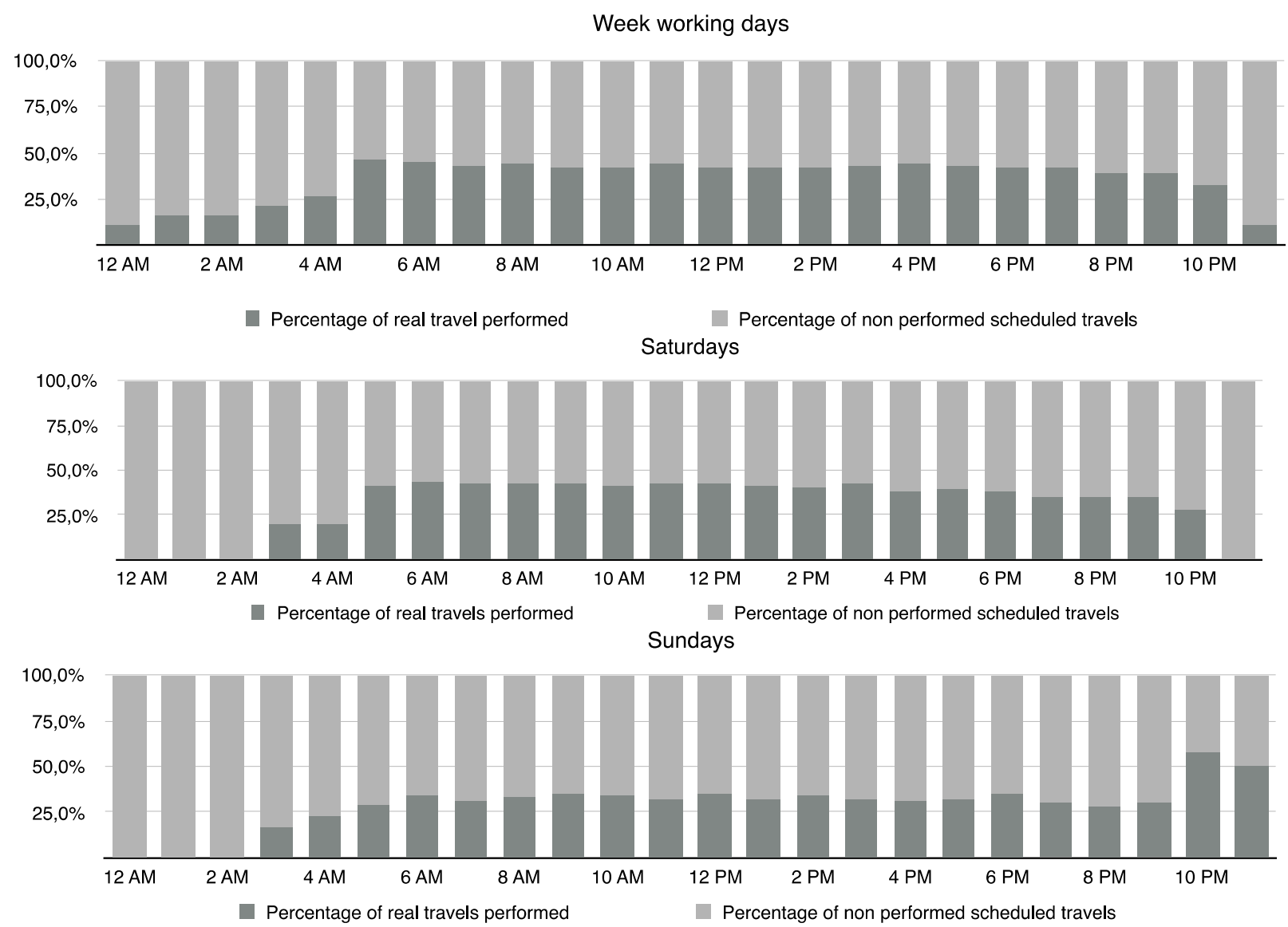

Fig. 8: Percentage of performed service on daily schedule (Self-elaboration based on SMTT and State agency MOB 2017 datasets)

Finally, to make possible to assess the operation of the whole MTS, route by route, highlighting their relationship with the contextual social and built environment, as well the spatial coverage of the service given by this system, these charts and calculations are projected spatially on routes individually to comprehend which areas of the city are accessible 'On-Peak' and 'Off-Peak'. Those spatial projections are here considering previous assessments on existing literature focusing on bus catchment areas (Park 2008; Daniels and Mulley, 2013; Tilahun et al., 2016). Therefore, the service area range of $400 \mathrm{~m}$ is used as reach distance from each station since there is lack of adequate sidewalk and pavement in the city (IBGE, 2016d).

\section{Results}

A qualitative method based on in situ empirical observations lead to witness long headway, overcrowded buses often present all day long, what also stimulates informal transport. As São Luís' MTS does not have dedicated lanes by the time of this investigation, such symptoms are often caused by two factors: i) a bus stuck in traffic congestion, or ii) a quick rise of the number of passengers, since the boarding of a certain number of people may slow down the process of forming a line to pay the ticket on board, hence increasing the time the bus is stopped at the station. Although both factors are visually tracked 'On-Peak' periods, it doesn't justify the very poor headway or overcrowds on 'Off-Peak' periods.

The assessment of quantitative data revealed precise results. Initially, despite the "Off-Peak" period from 9 am until $4 \mathrm{pm}$ seems flat and stable on number of travels (Figure 6), there is a significant variation on routes available during this time. To compare, the number of routes operating in a peak hour reaches 80 , while during 'Off-Peak' the average routes active is 50 , which is $20 \%$ of the 243 lines of both systems together. It happens as most of routes operate with stretched headway on 'Off-Peak' with a very small number of performed travels among the 'Off-Peak' period. In other words, some routes have longer than $60 \mathrm{~min}$ headway. This long 
headway is worsened on a capillary system based on trunks and feeders or hub and spoke, which often means to transfer among routes is needed and can be even worse when applied the percentage of performed travels per hour. As seen, there are several leaks on the planned schedule and the effective performed service (Figure 8). From the total daily activity, 56 lines are performing less than $40 \%$ of planned scheduled travels. However, there is a fluctuation showing eight lines are delivering service above the number of planned travels scheduled. As longer than $60 \mathrm{~min}$ is not an attractive headway to commute or integrate, hence social exclusion is here considered, rising difficult to access places. Hence, by visualizing this information spatially, the following result is obtained on working days (Figure 9 and 10).

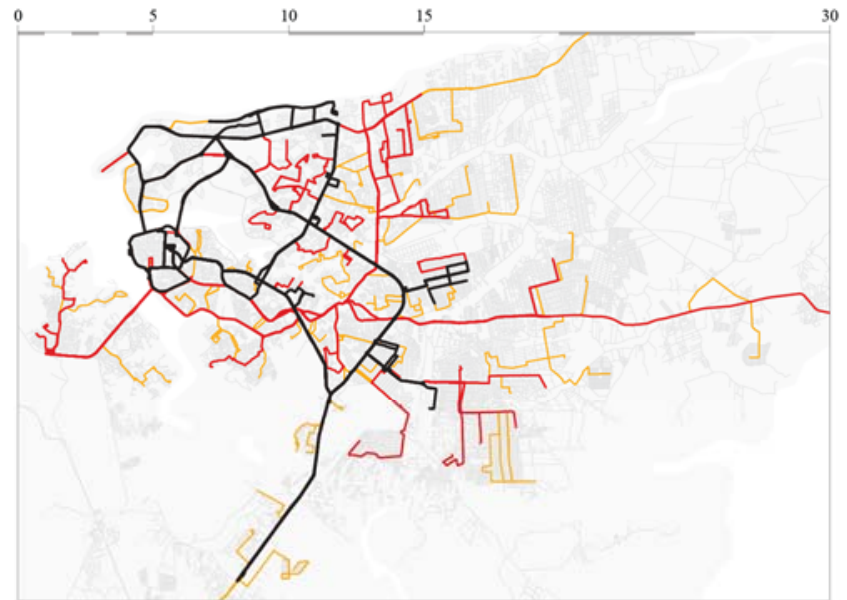

Routes with headway longer than $60 \mathrm{~min}$ are here avoided

- 30-60 min headway

- 15-30 min headway

- 8-15 min headway

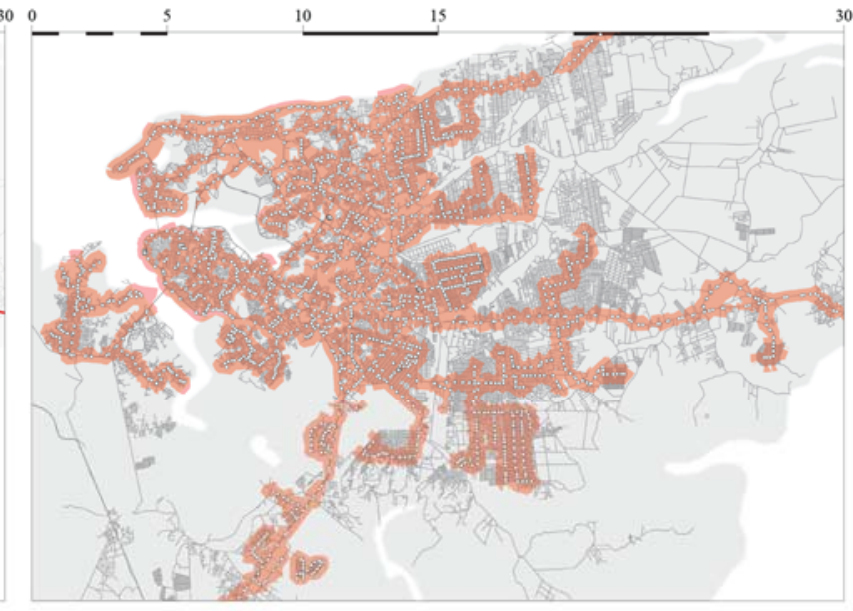

Island

Roads network

$5 \mathrm{~min}(400 \mathrm{~m})$ walking range from working stations

Fig. 9: The 'On-Peak' network (left) and its station coverage (right) on working days

The 'On-Peak' network coverage seems fair when compared with the maximum MTS' coverage previous shown here (Figure 5). However, the routes with a short headway 'On-Peak' time period do not cover well the whole city. Moreover, the situation shown 'Off-Peak' on working days demonstrates the expected low accessibility of some regions of the city as follows:

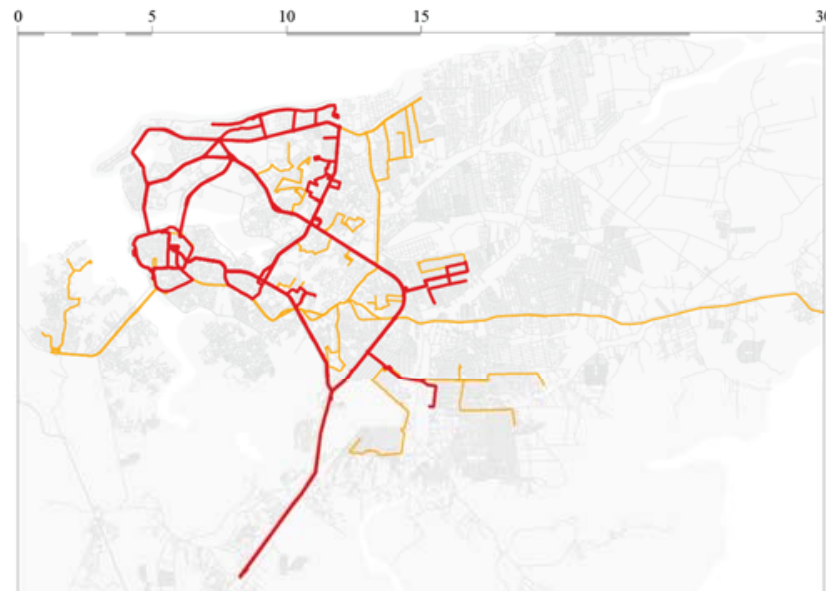

Routes with headway longer than $60 \mathrm{~min}$ are here avoided

- 30-60 min headway Island

- 15-30 min headway Roads network

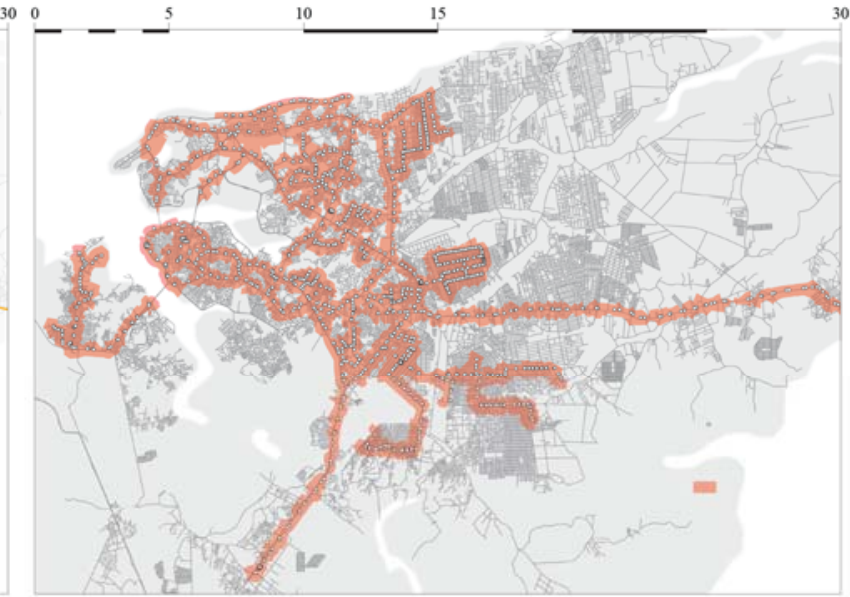

Island

Roads network

$5 \mathrm{~min}(400 \mathrm{~m})$ walking range from working stations

Fig. 10: The 'Off-Peak' network (left) and its station coverage (right) on working days (Self-elaboration based on SMTT and State agency MOB 2017 datasets) 
Nevertheless, the scenario over the weekends is even more unsatisfactory (Figure 11 until Figure 14). As mentioned before, most of the beach and park areas located on the north side of the island, here are shown as inaccessible with headways higher than $60 \mathrm{~min}$. It should be highlighted that a headway longer than $60 \mathrm{~min}$ may be not only inconvenient to increase time travel when making transfers, as also limits the number of available seats to reach a certain region.

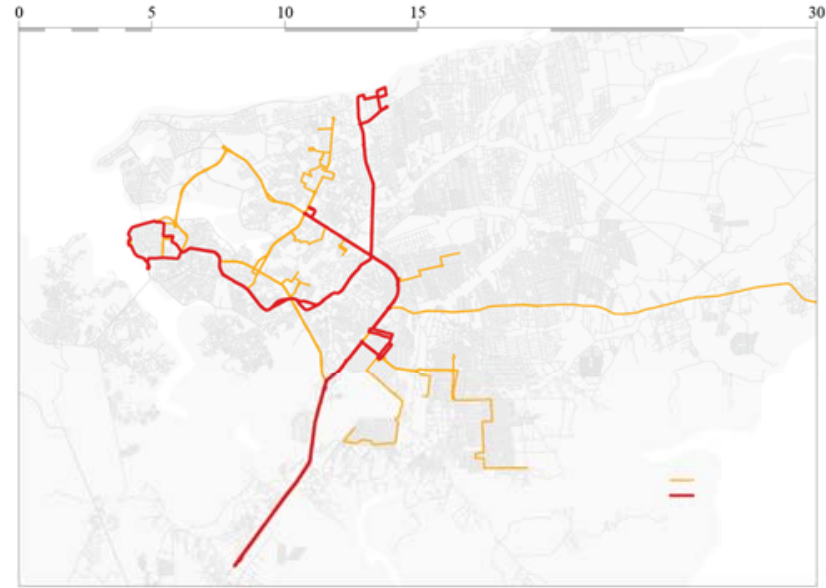

Routes with headway longer than $60 \mathrm{~min}$ are here avoided

- 30-60 min headway

- 15-30 min headway

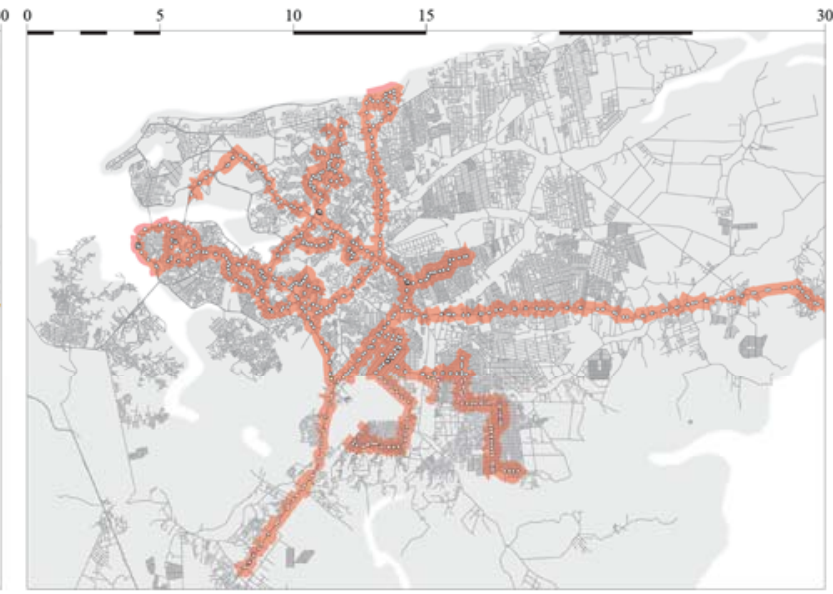

Island

Roads network

$5 \mathrm{~min}(400 \mathrm{~m})$ walking range from working stations

Fig. 11: The 'On-Peak' network (left) and its station coverage (right) on Saturday (Self-elaboration based on SMTT and State agency MOB 2017 datasets)

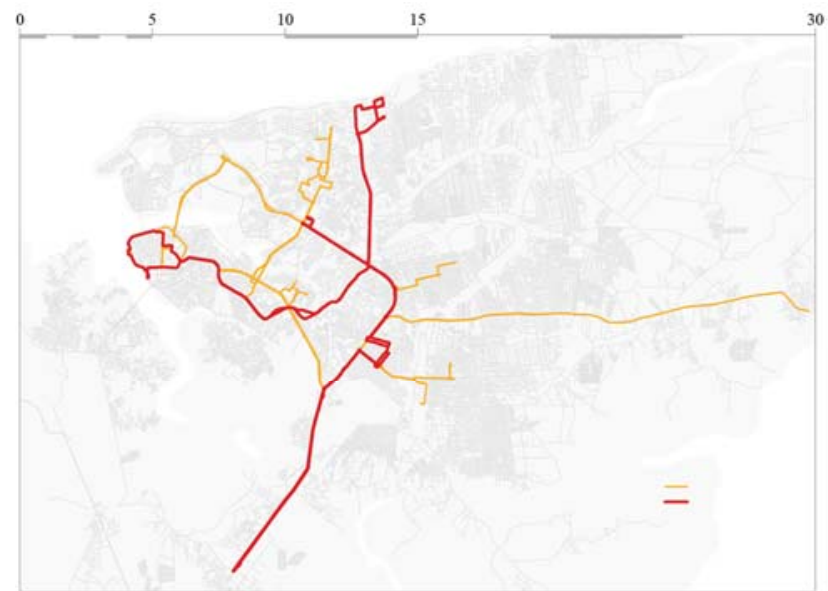

Routes with headway longer than $60 \mathrm{~min}$ are here avoided

- 30-60 min headway Island

- 15-30 min headway

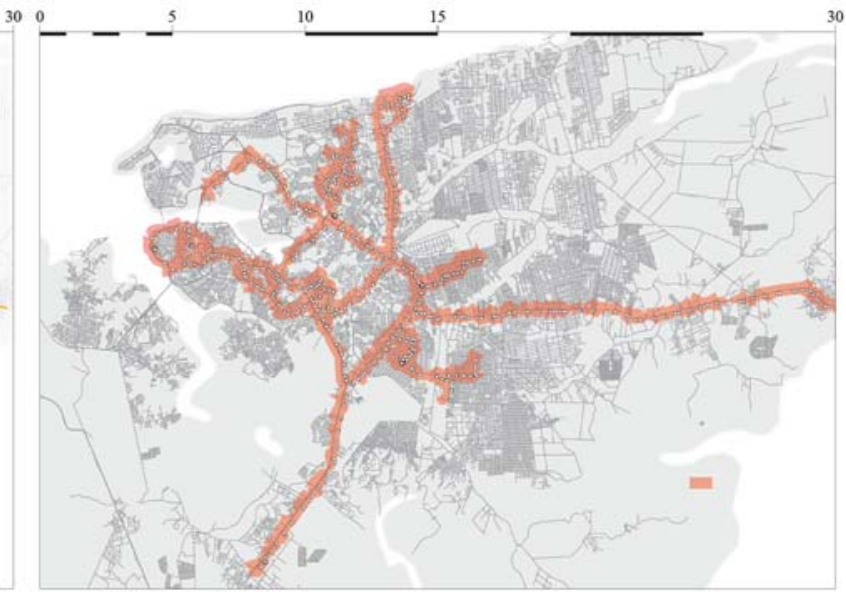

Island Roads network

$5 \mathrm{~min}(400 \mathrm{~m})$ walking range from working stations

Fig. 12: The 'Off-Peak' network (left) and its station coverage (right) on Saturday (Self-elaboration based on SMTT and State agency МОВ 2017 datasets) 


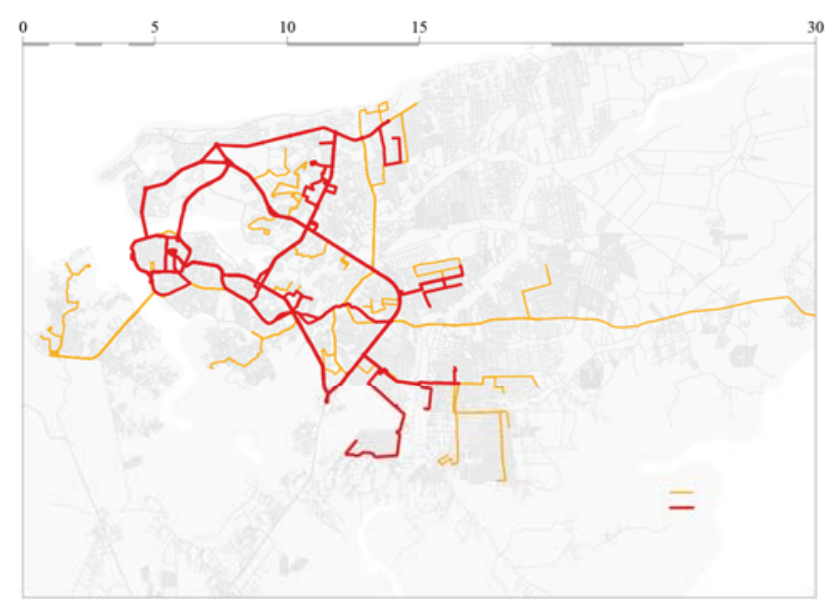

Routes with headway longer than $60 \mathrm{~min}$ are here avoided
- 30-60 min headway
Island
- 15-30 min headway
Roads network

Fig. 13: The 'On-Peak' network (left) and its station coverage (right) on Sunday (Self-elaboration based on SMTT and State agency МОВ 2017 datasets)

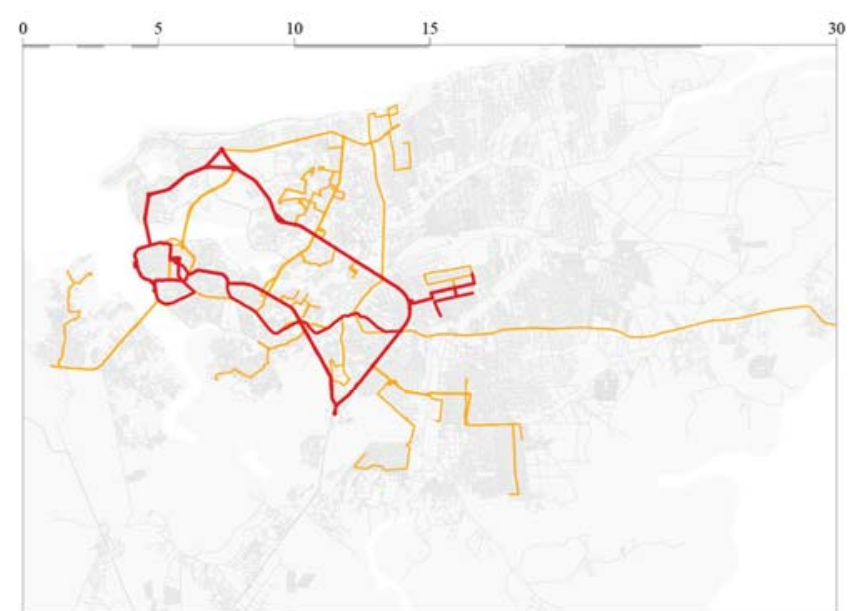

Routes with headway longer than 60 min are here avoided
- 30-60 min headway
Island
- 15-30 min headway
Roads network

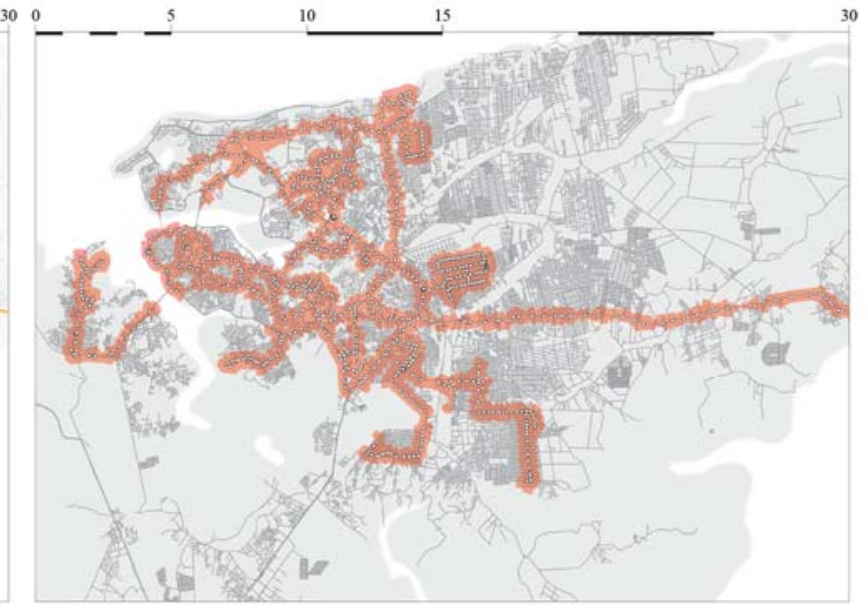

Island

Roads network

$5 \mathrm{~min}(400 \mathrm{~m})$ walking range from working stations

$5 \mathrm{~min}(400 \mathrm{~m})$ walking range from working stations

agency МОВ 2017 datasets)

\section{The network topology}

As exposed before in Figure 4 and Figure 5, the MTS of this case-study works based on a Hub and Spoke model. To follow this model, the system slices its network among feeders and trunks, feeding different terminals. This concept still broadly applied worldwide and recommended by recent references considering its operational advantages to manage its costs (Wright \& Hook, 2008). However, same authors acknowledge a significant disadvantage for its users, recognizing the penalty to make a transfer (Ibid). The hierarchy proposed in a Hub and Spoke system is also applied by defining the system in «trunk-feeders» services. That is, assigning to a trunk the function of «hub». Newell (1979) defends the hub in different models, for instance, identifying in the trunk line as a big «Hub» extended by a long street. The author defends the explicit economic advantage when using the trunk as a hub: by cutting the previous 'tail' of lines in pieces of new small routes, it manages to reach a better calibration of each part of the system to match the service to the demands of each area. The same method also is used to force the canalization of the demand to a specific station or axis, hence justifying the improvements at the trunk, due that its demand is increase by the sum of all feeders' branches. 
One recent example is the case of Transantiago in 2007, where bus routes were literally cut to canalize and force people to use the metro (ACTUS. 2015). However, a system divided into many pieces often forces the users to do one or more transfers. Furthermore, such hierarchy ends to concentrate the higher demand in the trunk, what calls for a very high frequency in that corridor. However, on the other side, the feeder ends with a scattered number of passengers, which low scattered demand can invite operators to work with long waiting times, being served by a very a poor headway.

The concept of Hub and Spoke networks and its advantages have been applied largely since the seventies, by following the yet acknowledged names on this literature, like Newell, Vuchic \& Byrne. On another side, there is Thompson (1977), who acknowledged early in those years that the city is more than the CBD, joining into this dialog proposing a grid system. The author investigates different models of network, also identifying that is possible to apply routing schemes based on «Hub \& Spoke» whatever is the shape of the urban form. If the roads network permit, bus routes radiate from/to downtown like spokes of a wheel. If the road network has a grid shape, the routes will look like multipronged pitchforks. However, whether the system appears to look like spokes or pitchforks, they will function as a radial (Thompson, 1977). Thompson's ideas do not exclusively define a right or wrong system but clearly advocates for the creation of a different model that considers the «multi-destination» feature.

For this, he examined the alternative method called «Ubiquitous» transit service. The method describes a hypothetical transit system allowing direct travel opportunity between all origins and destinations (Ibid.). Unfortunately, the technique is considered unrealistic, due to the requirement of a high quantity of services, so even the most densely populated urban area may struggle to generate a ridership to support it (Ibid.). However, to connect a city as a whole, Thompson proposes an equilibrated system: where the system is not costly and therefore can invest in better higher frequencies. Thus, he analyzes two grid options, first considering horizontal and vertical routes, where all vertical routes create transfer stations with horizontal lines. In this way is offered ubiquitous connectivity, although a transfer shall be involved for most of the trips, all area would be covered by a similar path. Thompson also proposes a 'grid system' that may not rely on a grid-shaped urban form. The routes are shaped in a cycle system, making possible to reach most of the destination with one or no transfer. According to Thompson (1977), this type of system resembles to attract three to four times more passengers than the standard radial systems.

Taking into account the previous analysis exposed here in this paper is clear that the Hub and Spoke models could hide a leak in its capillarity. It reveals that the network in itself has no capillarity, but its hubs. It exhibits the other angle of a system strongly based on hierarchy. Furthermore, as the system has its routes sliced between feeders and trunks, the organization of its timetable ends to be determinant to define whenever the passenger will be able or not to perform commuting to specific destinations.

By observing the previous maps revealing the lack of coverage of the case study MTS, it depicts most of the area covered is the between axis among the existing hubs. Secchi (2015) states that isotropy opposes to hierarchy: hierarchy brings the idea of command, fragmentation, specialization, and subordination. Therefore, following this conceptualization, the previous mentioned Ubiquitous network from Thompson would act as an extreme isotropic model. 


\section{Conclusion}

We conclude this study on assessing the daily activity of São Luís' MTS network by indicating the evidence of temporal unavailability and instability based on the percentage of performed services from each route schedule individually. As well how it accentuates social exclusion by carrying inconsistent and long headways to access specific city areas (as shown before on spatial analysis Figure 9 until Figure 14), which does not ease access equally the public assets. As the most vulnerable population of São Luís depends on MTS to commute to work, study and leisure purposes, they end up constrained to inadequate and insufficient service. Nevertheless, time-dependent does not define this slice of the population, since the significant percentage of non-performed travels revealed disclosing the concern on conditional uncertainty: the route is whether delayed or not working today. Thus, it creates a limited service that discourages people from using public transit as also to travel to some wealthy areas of the city. Furthermore, as low-income people do not have other options to commute, they end up as a significant amount of population excluded systematically to reach to certain areas of the city. Hence, the system culminates in working as a reinforcement of social segregation.

Time fluctuation, time variability, or inconsistency of availability of the routes are such factors to print a not reliable MTS, affecting the accessibility to specific areas of the city in different levels. As it reduces consistently the number travels scheduled, it reduces the system capacity as well, therefore increasing the possibility of overcrowding buses even on Off-Peak hours, whereas the lack, absence or reduced services of MTS motivates its users to buy a private mode of transport. When having into account the income condition, the motorcycle appears as a first affordable option or using the informal options of transport, as seen in qualitative observations. Hence, informal transport is confirmed here as an impromptu answer to counterproductive gaps left by a public MTS (Talamini et al., 2017). Among observed informal transports options offered on crowded bus stations, there were observed motorbikes offering one-seat express travel, or private vehicles stopping by and screaming a dropping off neighborhood name. MTS' users often decline those informal modes of transport since most of those users have already a pre-paid electronic ticketing card. Further studies would be needed to provide a more solid base for this spontaneous, informal transit background.

The capillary of this system seems evident in Figure 5. However, to affirm that the system has capillarity, does not ensure automatically that its network is capillarity. Although routes showed in Figure 5 are reaching several areas of the city, the analysis performed in this paper displayed the unavailability of several routes in different periods of the day or week. It revealed a property hidden behind the topology of the routes: that the capillarity occurs to relate to its hubs instead of a property of the network. The analysis of the MTS demonstrates a system well connected to the city center, whereas other areas of the city have limited access, disintegrated or not well contemplated. It shows this pattern due to prevail a Hub and Spoke with Trunk and Feeders routes profile, which has its topology clearly denying concepts of isotropy. As identified by Orrico (2013) the current multipolar city, where the central area does not lead the centrality erstwhile, has a high amount of new activities divided among all its urban space. In this way reveals the necessity of modeling a new mass transit system that not only responds to users' wishes but also enhances urban synergies and supports the planned growth. 


\section{Bibliography}

Bertoncini, B.V. (2010). Uma proposta de estimação da matriz OD a partir dos fluxos de tráfego observados nas interseções da rede de transportes. São Carlos, SP: USP.

Byrne, B. \& Vuchic, V. (1972). Public transportation line positions and headways for minimum cost. Journal of Traffic flow and transportation. 347-360.

CAF, Banco de Desarrollo de América Latina (2011) Desarrollo Urbano y Movilidad en America Latina. Panamá: observatório de movilidad urbana.

Daniels, R. \& Mulley, C. (2013). Explaining walking distance to public transport: the dominance of public transport supply. Journal of Transportation and Land use (Sidney), 6, 2, 5-20.

Daros, J.E., (1995). Congestionamento de Trânsito em nossas metrópoles - proposta de solução. ANTP Journal, (Brasília), 7, 61-66.

Fransen, K. et al. (2015). Identifying public transport gaps using time-dependent accessibility levels. In: Journal of Transport Geography (Helsinki), 48, 176-187.

Friesz, T.L., et al. (1992). Simulated annealing methods for network design problems with variation inequality constraints. Transportation Science, 26, 18-26.

Fernández, J.L., De Cea, J. \& Malbran, R.H. (2008). Demand responsive urban public transport system design: methodology and application. Transportation Research, 42, 951-72.

Ferreira, D., (2011a). The rescue of the old concepts for the city's future: case study of São Luís. Delft: TUDelft.

- (2011b): Cidade Dispersa. In: Vida Urbana. São Luís, MA: Jornal Imparcial Cidade, 3, pp.10-11.

- (2012): A cidade cresce e os problemas aparecem, São Luís: desafios de uma cidade quatrocentenária. Revista Periódica Imóvel e Negócios, (São Luís) 4-16, 22-26.

Ferreira, D. \& Araújo, P. (2013). Projetos Urbanos para a Região Metropolitana. Porto Alegre, RS: Metroplan.

Ferreira, D. \& Lagemann, F., (2016). Modeling mass transit nets and urban development strategies: the right to the city as a new framework to rethink systems'. In: 14th World Conference on Transport Research. 223227.

Gutiérrez, L.R. (2013). Transporte público de Qualidade e Mobilidade Urbana. In: Mobilidade Sustentável: para um Brasil mais competitivo, (Brasília), 26-38.

Harvey, D. (1988). Social Justice and the city. Oxford: Basil Blackwell.

IBGE, Instituto Brasileiro de Geografia e Estatística (2015b). Brazil in figures. Rio de Janeiro. p.444.

- (2010a): Brazilian Census. Rio de Janeiro.

- (2010b): Setores Censitários: arranjos populacionais de regiões metropolitanas. Rio de Janeiro..

Grengs, J., (2015). Nonwork accessibility as a social equity indicator. Sustainainable Transport Journal. 9, 114. 
Haggett, P. (1965). The spatial economy. American Behavioral Sciences. 22, 1, 151-167.

Ischia, U., (2016). La città giusta: idee di piano e atteggiamenti etici. Roma: Donzelli.

Lindau, L.A. et al. (2015). Oportunidades para qualificar e inovar o transporte por ônibus nas cidades brasileiras. Porto Alegre, RS: Lastran.

Lösch, A. (1954). Economics of Location. London: Yale University Press.

Marks, M., Manson, J. \& Oliveira, G., (2016). People near transit. New York: ITDP.

Mendonça, F.A.F. (2016). Reestruturação de redes de transporte coletivo a partir da identificação de centralidades em cidades de medio porte: procedimento metodologico e definição de diretrizes. Goiânia, GO: UFG.

Metroplan. (2013). Proposta de Rede Integrada de Transportes para a Região Metropolitana de Porto Alegre. Porto Alegre, RS: Seplan.

Newell, G.F. (1979). Some Issues Relating to the Optimal Design of Bus Route. Transportation Science. 13. 1. $\mathrm{pp}-20-35$.

Orrico, R. et al. (2012). Mobilidade urbana sustentável: questões do porvir. Rio de Janeiro, RJ: Fundação COPPETEC.

Orrico, R. (2013). Redes de Transportes coletivos urbanos: eficiência e sustentabilidade. Rio de Janeiro: Coppe/UFRJ.

Ortúzar, J. D. \& Willumesen, L. G., 2001. Modelling transport. Chichester: John Wiley \& Sons.

Park, S. 2008. Defining, measuring and evaluating path walkability and testing its impacts on transit user's mode choice and walking distance to the station. City and Regional Planning. Berkeley: University of California.

Secchi, B. (2016). La nuova questione urbana: democrazia spaziale, ecologia e libertà di movimento. In: Ischia, U. La città giusta: idee di piano e atteggiamenti etici. Roma: Donzelli. pp-5-25.

- (2015). II futuro si costruisce giorno per giorno: riflessioni su spazio, società e progetto. Roma: Donzelli editore.

- (2013). La città dei ricchi e la città dei poveri. Roma: Anticorpi Laterza.

Sen, A., (2009). The Idea of Justice. London: Allen Lane.

Smtt, Secretaria Municipal de Transportes de São Luís (2017). Official financial report: from December 2016 until February 2017. São Luís, MA: Secretaria de Transito e Transportes.

Soja, E.W. (2010). Seeking spatial Justice. Minneapolis, MN: University of Minnesota Press.

Talamini, G., Ferreira, D. \& Wang, Y., (2017). Impact of policing on unregulated e-bike taxicabs, in Shenzhen, China. Shenzhen, GZ: Harbin Institute of Technology.

Tenkanen, H. et al. (2016). Health research needs more comprehensive accessibility measures: integrating time and transport modes from open data. International Journal of Health Geographics. 15-23. 
Thompson, G.L. (1977). Planning Considerations for Alternative Transit Route Structures. Journal of American Institute of Planners. 42. 2. 158-168.

Tilahun, N. et al. (2016). Transit use and the work commute: Analyzing the role of last mile issues. Journal of Transport Geography, (Glasgow), 54, 359-368.

Woldeamanuel, M. \& Kent, A. (2016). Measuring Walk Access to Transit in terms of Sidelwalk availablility, quality and connectivity. Journal of Urban Planning Development (California), 2, 190-203.

Wright, L. \& Hook, W. (2008). Manual de BRT, Guia de planejamento. New York, NY: ITDP.

\section{Digital sources}

ACTUS. (2015). Lo que no se dice del Transantiago. [Online] Available from: https://goo.gl/mTbb3e [Accessed 11 October 2017].

Azevedo, A. (2016). Avesso 05-07-16. [online] Available at: < http://www.mob.ma.gov.br/acoes-da-mob-emdestaque-no-programa-avesso/ > [Accessed 22 April 2017].

Brasil, (2016). Proposta de Emenda Constitucional, PEC 90/2015. [on line] Available at: $<$ http://www.camara.gov.br/proposicoesWeb/fichadetramitacao?idProposicao=522343> [Accessed 2 December 2016].

Brasil, (2015). Política Nacional de Mobilidade Urbana. In: Caderno de referência para elaboração de plano de mobilidade urbana: planmob. Brasília, DF: Ministério das Cidades, Governo Federal do Brasil. pp.25-30. [online] Available at: <http://www.cidades.gov.br/images/stories/ArquivosSE/planmob.pdf>. [Accessed 13 June 2015].

Denatran, Departamento Nacional de Transito do Ministério das Cidades (2017). Dados oficiais do Governo Federal do Brasil. [online] Available at: < http://www.denatran.gov.br/index.php/estatistica/261-frota-2016>. [Acessed 21 April 2017].

IBGE, Instituto Brasileiro de Geografia e Estatistica (2016a). Municipality Summary: population estimated in 2016. [online] Available at: < http://www.cidades.ibge.gov.br/v3/cidades/municipio/2111300 >[Accessed 21 April 2017].

- (2016b). Cadastro Central de Empresas 2014. Instituto Brasileiro de Geografia e Estatistica - IBGE. [online] Available at: < http://cidades.ibge.gov.br/v3/cidades/municipio/2111300/pesquisa/19/2014 > [Accessed 2 December 2016].

- (2016c). Trabalho. 3.2. Instituto Brasileiro de Geografia e Estatistica - IBGE. [online] Available at:

< http://www.cidades.ibge.gov.br/v4/brasil/ma/sao-luis/panorama > [Accessed 2 April 2017].

- (2016d.) Territorio e Meio Ambiente. 3.1. Instituto Brasileiro de Geografia e Estatistica - IBGE. [online] Available at: < http://www.cidades.ibge.gov.br/v4/brasil/ma/sao-luis/panorama > [Accessed 2 April 2017].

MTA. Municipal Transit Agency of Baltimore, (2015) Baltimore Network Design: MTA Baltimore Link. [online] Available at: <https://mta.maryland.gov/baltimorelink/service/network-redesign> [Acessed 12 March 2017].

TMB, Transports Metropolitans Barcelona (2017). La Nova Xarxa Orthogonal de Transport. Barcelona: TMB. [online] Available at: < https://www.tmb.cat/ca/sobre-tmb/millores-xarxa-transport/nova-xarxa-bus > [Acessed 21 April 2017]. 